http://ojs.stikes-muhammadiyahku.ac.id/index.php/herbapharma

\title{
FORMULASI SEDIAAN SABUN MANDI PADAT DARI EKSTRAK ETANOL UBI JALAR UNGU (Ipomea batatas Linn.) SEBAGAI ANTIOKSIDAN
}

\author{
Wawang Anwarudin, Ririn Riandini
}

Program Studi Farmasi, STIKes Muhammadiyah Kuningan

*E-mail : rriandini07@gmail.com

\begin{abstract}
ABSTRAK
Ubi jalar ungu ( ipomea batatas linn ) memiliki aktivitas antioksidan, kandungan senyawa kimia =yang terkandung dalam ubi jalar ungu yang berfungsi sebagai antioksidan adalah senyawa antosianin. Penelitian ini bertujuan untuk mengetahui apakah ekstrak etanol ubi jalar ungu dapat diformulasikan sebagai sediaan sabun mandi padat dan pada konsentrasi berapa ekstrak etanol ubi jalar ungu dapat diformulasikan sebagai sabun mandi padat. Ekstrak etanol ubi jalar ungu diperoleh dengan proses maserasi dan dibuat kosentrasi $8 \%$, 9\% dan $10 \%$. Sediaan sabun mandi padat kemudian dievaluasi meliputi organoleptis, uji $\mathrm{pH}$, uji kadar air dan uji tinggi dan stabilitas busa. Pengujian dilakukan pada hari ke-1, hari ke-7 dan hari ke- 14 , hasil uji organoleptik dilihat dari bentuk, warna dan bau, warna dan bau selama proses penyimpanan hamper semua mengalami perubahan. Hasil uji pH sabun dari formula F0,F1,F2 dan F3 tetap stabil pada $\mathrm{pH}$ 10. Hasil uji kadar air semua formula tidak memenuhi SNI. Hasil tinggi dan stabilitas busa sudah memenuhi syarat SNI . Hasil penelitian menunjukkan bahwa ekstrak etanol ubi jalar ungu dapat diformulasikan menjadi sediaan sabun mandi padat dengan konsentrasi ekstrak etanol ubi jalar ungu $10 \%$ yaitu $\mathrm{F} 3$,yang memenuhi syarat evaluasi uji $\mathrm{pH}$ dan uji tinggi dan stabilitas busa,tetapi belum memenuhi syarat uji kadar air.
\end{abstract}

Kata Kunci :Antioksidan, Ekstrak Etanol Ubi Jalar, Sabun Mandi Padat.

\begin{abstract}
Purple sweet potato (ipomea batatas linn) have activity antioxidants content coumpound chemistry that contained in ubijalarungu that function as antioxidants is coumpound anthocyanin. Research this aiming for knowing is extract etanol Purple sweet potato could formulated as soap bath solid and on concentration how many extract etanolubijalarungu could formulated as sold bath solid. Extract etanol Purple sweet potato in obtain it with maceration and in make it concentation $8 \%, 9 \%$ and $10 \%$. Preopation soap bath solid then in evalution convers test organoleptic, test $\mathrm{pH}$, test water content and test hingh and stability foam. Testing in done on day to-1, to-7 and to,14, results test organoleptic seen from, color and smell, forr process storage almost all experience change. Result test $\mathrm{pH}$ soap from formulation F0,F1,F2 and F3 permanent stable on pH 10. Result test water content all formulation not meet SNI. Result test high and stability foam I have meet terms SNI. Result research shows that Extract etanolubijalarungu could in formulation to the soap with concentration Extract etanolubijalarungu $10 \%$ that is $\mathrm{F} 3$. That meet terms evalution test $\mathrm{pH}$ and test high and stability foam, but not yet meet terms test water content.
\end{abstract}

Keywords :Antioxidants, Purple Sweet Potato, Solid Bath Soap. 


\section{PENDAHULUAN}

Di zaman modern ini kosmetik merupakan kebutuhan bagi semua kalangan baik anakanak, remaja bahkan orang dewasa memakai kosmetik, kosmetik ini bukan lagi kebutuhan (sekunder), tetapi di zaman sekarang ini kosmetik merupakan kebutuhan yang memang sangat dibutuhkan (primer), hamper semua kalangan menggunakan kosmetik karena untuk mempercantik diri dan mengubah penampilan.Dengan banyak pilihan dan varian kosmetik, ada yang tabur, krim, padat maupun cair. Semua varian ini Memiliki ciri khas tersendiri, tergantung kebutuhan pemakai. Sebelum banyaknya berbagai varian dan jenis-jenis kosmetik, ada jenis kosmetik padat lebih banyak di gunakan oleh orang-orang seperti sabun.

Sabun merupakan kebutuhan bagi semua kalangan mulai dari anak-anak orang dewasa dan bahkan lansia menggunakan sabun pada saat mandi karena berfungsi untuk membersihkan badan dan kulit, sabun memiliki 2 macam bentuk sabun padat dan sabun cair, tetapi kebanyakan orang menggunakan sabun mandi padat karena mudah didapat, mudah dipakai, dan memiliki harga yang ekonomis, Sabun mandi juga memiliki banyak jenis dan macam, ada yang untuk kesehatan dan kecantikan. Sabun padat dibuat dari berbagai bahan, ada yang dari bahan alami seperti dari ekstrak buah-buah dan tanaman dan bahan kimia. Dan saya sebagai penulis sangat tertarik untuk memformulasikan sabun mandi padat dari ekstrak etanol ubi jalar ungu sebagai antioksidan, karena untuk mengetahui konsentrasi yang paling baik dari sabun mandi padat ekstrak etanol ubi jalar ungu sebagai antioksidan dan mengetahui apakah ekstrak etanol ubi jalar ungu dapat di formulasikan sebagai sabun atau tidak.

Penambahan bahan yang berkhasiat pada sabun di harapkan dapat menghambat pertumbuhan bakteri. Banyak ubi-ubian ataupun tanaman dan buah yang sampai saat ini belum bisa di manfaatkan dengan baik, termasuk ubi jalar ungu. Pada dasarnya ubi jalar ungu dapat digunakan untuk formulasi sediaan sabun mandi padat sebagai antioksidan yang sangat di butuhkan oleh tubuh pada kulit untuk melawan radikal bebas dari luar.

Di dalam ubi jalar ungu mengandung senyawa antosianin yang berfungsi sebagai antioksidan dan penangkap radikal bebas, sehingga berperan untuk mencegah terjadi penuaan,kanker,dan penyakit degenerative. Selain itu, antosianin juga memilikikemampuan sebagai anti mutagenik dan antikarisinogenik, mencegah gangguan fungsi hati, antihipertensi, dan menurunkan kadar gula darah (Jusuf,dkk 2008).

Ubi jalar ungu sangat banyak mengandung zat warna, terutama antosianin yang kandungannya berkisar antara 14,68-210 mg/100 gram bahan. Antosianin ini merupakan antioksidan alami yang dapat mencegah penyakit kanker, jantung, tekanan darah tinggi, dan bahkan dapat menghaluskan kulit (Juanda,2000).

Berdasarkan hasil penelitian dari fakultas Pertanian Ubud di Bali ditemukan kandungan antosianin dari ubi jalar putih sebesar $0.06 \mathrm{mg} / 100$ gram bahan, ubi jalar kuning sebesar 4,56 $\mathrm{mg} / 100$ gram bahan, sedangkan ubi jalar ungu berkisar $110-210 \mathrm{mg} / 100$ gram bahan (Suprapto,2004).

Berdasarkan uraian diatas saya sebagai penulis sangat tertarik untuk melakukan penelitian untuk sebuah karya tulis ilmiah, yaitu, "formulasi sediaan sabun mandi padat dari ekstrak etanol ubi jalar ungu (Ipomea batatas Linn) sebagai Antikosidan".

\section{BAHAN DAN METODE}

\section{Bahan dan Alat}

Bahan yang digunakan dalam penelitian iniadalahh etanol $70 \%$, ubi jalar ungu, minyak zaitun, minyak kelapa, meinyak sawit, $\mathrm{NaOH}$, Oleum Rosae, Aquadest. Alat yang digunakan dalam penelitiann ini adalah kertas $\mathrm{pH}$ Universal, oven listrik, tabung reaksi, penggaris, hand blender. 


\section{Jenis Penelitian}

Penelitian ini adalah penelitian eksperimental. Tahap pertama adalah determinasi tanaman selanjutnya dilakukan pembuatan serbuk simplisia ubi jalar ungu. Serbuk simplisia ubi jalar ungu di ekstraksi menggunakan metode maserasi menggunakan pelarut etanol $70 \%$. Ekstrak etanol ubi jalar ungu di formulasikan kedalam sabun mandi padat. Evaluasi sifat fisik sabun mandi padat meliputi uji organoleptic $\mathrm{pH}$, kadar air, tinggi dan stabilitas busa.

\section{Prosedur Penelitian}

Pembuatan Sabun Mandi Padat

Pembuatan sabun dengan cara melarutkan $\mathrm{NaOH}$ dalam aquadest,dicampurkan minyak kelapa, zaitun, dan minyak sawit, di panaskan hingga mencapai suhu 700C. dimasukan larutan $\mathrm{NaOH}$ kedalam campuran minyak sedikit demi sedikit, diaduk sampai homogenya hand blender dan terjadi itrace (kondisi dimana sabun sudah terbentuk dengan tanda masa sabun mengental). Ekstrak etanol ubi jalar ungu ditambahkan pada saat trace tersebut, diaduk kembali hingga homogen. Massa sabun yang masih berbentuk cair dituangkan kedalam cetakan sabun dan didiamkan selama 24 jam sampai mengeras.

Tabel 1. Formulasi Sediaan Sabun Mandi Padat dan Ekstrak Etanol Ubi Jalar Ungu

\begin{tabular}{lllll}
\hline Komposisi & F0\% & F1\% & F2\% & F3\% \\
\hline Ekstrak ubi jalar ungu & - & 8 & 9 & 10 \\
Minyak Zaitun & 10 & 10 & 10 & 10 \\
Minyak Kelapa & 20 & 20 & 20 & 20 \\
Minyak Sawit & 30 & 30 & 30 & 30 \\
NaOH & 8,9 & 8,9 & 8,9 & 8,9 \\
Oleum Rosae & 2 & 2 & 2 & 2 \\
Aquadest ad & 100 & 100 & 100 & 100 \\
\hline
\end{tabular}

\section{Analisis Data}

a. Uji Organoleptik

Uji ini dilakukan dengan cara dilihat dari bentuk, warna, dan bau dari sabun pada penyimpanan selama 2 minggu.

b. Uji Ph

Sejumlah sabun dilarutkan dalam air sampai larut. pH diukur dalam masing - masing formula sabun ekstrak etanol ubi jalar ungu dengan menggunakan kertas indicator pH.Pengamatan dilakukan selama 2 minggu untuk mengetahui perubahan nilai $\mathrm{pH}$ sabun mandi padat.

c. Uji Kadar Air

Penetapan kadar air dari sabun, dilakukan dengan metode gravimetri. Ditimbang 4 gram sabun yang telah disiapkan dan telah di timbang lalu di panaskan dalam oven pada suhu 1050C selama 2 jam dan didinginkan.

d. Tinggi dan Stabilitas Busa

selama 1 menit. Busa yang terbentuk diukur tingginya menggunakan penggaris (tinggi busa awal). Tinggi busa diukur kembali setelah 1 jam (tinggi busa akhir), kemudian stabilitas busa dihitung dengan rumus.(Mauliana. 2016) 


\section{HASIL DAN PEMBAHASAN}

Pembuatan simplisia dari $3 \mathrm{~kg}$ ubi jalar ungu didapatkan hasil randemen sebesar $20,495 \%$ serbuk simplisia yang peroleh warna coklat tua aroma ubi jalar ungu. Hasil pembuatan simplisia dapat di lihat pada Tabel 2.

Tabel 2. Hasil Ekstrak Etanol Ubi Jalar Ungu

\begin{tabular}{ccc}
\hline No & Pengamatan & Hasil \\
\hline 1 & Warna & Coklat tua \\
\hline 2 & Aroma & Aromatic \\
\hline 3 & Ekstrak & 40,99 \\
\hline
\end{tabular}

Serbuk simplisia yang telah di buat di ayak dan di timbang sebanyak 200 gram untuk dilakukan pembuatan ekstrak etanol ubi jalar ungu. Pembuatan ekstrak etanol ubi jalar ungu dilakukan dengan metode maserasi dengan pelarut etanol $70 \%$. Metode maserasi digunakan karena merupakan cara ekstraksi yang sederhana. Etanol $70 \%$ digunakan sebagai pelarut karena sebagian besar senyawa polar dan semi polar dapat terekstraksi.

Maserasi dilakukan dengan cara 200 gram serbuk simplisia di rendam dengan 1 liter pelarut etanol $70 \%$ dan di asamkan dengan $\mathrm{HCl} 1 \%$. Perendaman dilakukan selama 3 hari sambil sesekali diaduk, kemudian disaring dan hasil filter yang sudah disaring kemudian di panaskan diatas waterbath.

Hasil ekstrak yang sudah kental dan hasil yang si dapatkan ekstrak kental berwarna coklat tua dengan aroma ubi jalar ungu. Hasil maserasi didapat ekstrak kental sebanyak 40,99 gram dengan randemen ekstrak sebanyak $20,499 \%$ hasil pembuatan ekstrak etanol ubi jalar ungu dapat dilihat pada Tabel 3.

Tabel 3. Hasil Rendaman Ekstrak

\begin{tabular}{ccc}
\hline No. & Pengamatan & Hasil \\
\hline 1. & Warna & Coklat Tua \\
\hline 2. & Aroma & Aromatic \\
\hline 3. & Bentuk & Kental \\
\hline 4. & Randemen & 20,495 \\
\hline
\end{tabular}

Pembuatan sabun mandi padat dengan menggunakan tiga jenis minyak dengan konsentrasi pada setiap formula yang dapat dilihat pada Tabel 1. Sabun dibuat dengan cara mencampurkan $\mathrm{NaOH}$ dengan campuran minyak yang telah dipanaskan hinggasuhu $70^{\circ} \mathrm{C}$. Tujuan dari pemanasan adalah untuk mempercepat reaksi saponikasi yang terjadi $\mathrm{NaOH}$ dituangkan sedikit demi sedikit sambil terus di aduk sampai terjadi trace. Trace adalah kondisi dimana masa sabun mandi terbentuk yang di tandai dengan masa sabun mengental, di tambahkan ekstrak etanol ubi jalar ung, dan dihomogenkan kembali dengan cara diaduk terus menerus sampai terjadi trace. Sabun yang di hasilkan berwarna coklat muda, aroma khas ubi jalar, masa sabun yang terbentuk di tuangkan ke dalam cetakan dan didiamkan selama 24 jam sampai sabun mengeras. 
Uji mutu sediaan sabun mandi padat dilakukan untuk mengetahui apakah sabun yang dibuat sesuai dengan SNI. Uji yang dilakukan pada penelitian ini adalah uji organoleptic, $\mathrm{pH}$,kadar air, tinggi dan stabilitas busa. Uji dilakukan selama waktu penyimpanan pada hari ke 1 , ke 7 dan ke 14 untuk mengetahui apakah ada perbedaan hasil selama penyimpanan.

Pengamatan organoleptic berupa pengamatan visual yang meliputi bentuk, warna, dan bau aroma sabun. Tujuan pengamatan untuk mengetahui perubahan bentuk fisik sediaan sabun mandi selama 2 minggu penyimpanan.

Hasil pengamatan bentuk memiliki bentuk oval.sabun pada hari pertama semua formula masih terrlihat tidak ada perubahan dari segi warna tidak mengalami perubahan. Pada hari ke-7 mengalami perubahan dari segi warna yang tadi berwarna coklat tua mengalami perubahan menjadi coklat muda dan pada hari ke-14 sangat berubah dari semua formula yang tadinya coklat muda berubah menjadi coklat pucat setelah didiamkan selama 14 hari.

Pengamatan aroma bau dari hari ke-1 semua formula sangat memiliki aroma khas bau ubi jalar ungu, hari ke-7 aroma dan ubi jalar masih terasa, meskipun edikit lemah dan pada hari ke-14 aroma dari ubi jalar ungu sudah tidak ada kecuali F3, masih terasa aroma ubi jalar ungunya meskipun sedikit lemah. Aroma yang sudah mulai hilang di sebabkan karena aroma tersebut telah menguap. Nilai pH pada sediaan sabun mandi padat merupakan hal penting karena milai $\mathrm{pH}$ menentukan apakah sabun mandi padat layak digunakan atau tidak. Nilai $\mathrm{pH}$ yang tinggi atau rendah dapat menambah daya absorbansi kulit sehingga memungkinkan kulit iritasi tetapi dari sediaan sabun mandi padat dari ekstrak etanol ubi jalar ungu dari hari ke-1,ke7 dan hari ke-14 memiliki pH yang stabil yaitu 10 artinya nilai pH sudah sesuai SNI.

Uji kadar air pada sediaan sabun mandi padat adalah pengukuran berat setelah pengeringan atau di oven pada suhu $105^{\circ} \mathrm{C}$ selama 2 jam berdasrkan SNI. Kadar air untuk sabun mandi padat maksimal $15^{\circ} \mathrm{C}$. hasil uji kadar air dari semua formula hari ke- 1 ,ke-7dan ke14 tidak ada yang memenuhi syarat SNI karena semua formula darisediaan sabun mandi padat ekstrak etanol ubi jalar ungu di atas $15 \%$ karena pada saat di ovensuhu dari oven meningkat tidak stabil di suhu $105^{\circ} \mathrm{C}$, jadi hasil dari uji kadar air tidak ada yang sesuai, tetapi F3 mengalami penurunan pada hari ke-7 dan ke-14 meskipun kadar air tidak sesuai dengan SNI.

Pengamatan uji tinggi dan stabilitas busa syarat umtuk tinggi busa 1,2-2,2 cm sedangkan untuk stabilitas busa mencapai $100 \%$ bisa dikatakan memiliki stabilitas yang sangat yang sangat bagus untuk tinggi busa dihitung dari tinggi awal dan tinggi akhir sedangkan untuk stabilitas busa menggunakan rumus dan hasil dari tinggi busa, dari semua formula sediaan sabun mandi padat dari ekstrak etanol ubi jalar dari hari ke-1,ke- 7,dan ke-14 memiliki tinggi dan stabilitas yang sudah memenuhi syarat tetapi dari semua formula ada yang paling baik yaitu F3 memiliki tinggi dan stabilitas busa 65,04 paling bagus dibandingkan dengan formula yang lainnya.

Tabel 4. Hasil Uji Organoleptik, pH, Stabilitas dan Tinggi Busa

\begin{tabular}{|c|c|c|c|c|c|c|c|c|c|c|}
\hline \multirow{2}{*}{\multicolumn{2}{|c|}{ Urajan }} & \multicolumn{4}{|c|}{ Hari ke-1 } & \multicolumn{3}{|c|}{ Hari ke-7 } & \multicolumn{2}{|c|}{ Hari ke-14 } \\
\hline & & I & II & III & l & II & III & I & II & III \\
\hline Qrqanoleptik & Bentuk & 0 & 0 & 0 & 0 & 0 & 0 & 0 & 0 & 0 \\
\hline & Warna & $\mathrm{CM}$ & $\mathrm{CM}$ & CT & $\mathrm{CM}$ & CM & CT & CP & $\mathrm{CP}$ & CM \\
\hline & Aroma & UBI & UBI & UBI & UBI & UBI & UBI & UBI & UBI & UBI \\
\hline $\mathrm{Ph}$ & & 10 & 10 & 10 & 10 & 10 & 10 & 10 & 10 & 10 \\
\hline Kadar air & $\%$ & 26,75 & 23 & 32,5 & 36 & 31,5 & 30 & 34,23 & 32,5 & 26,25 \\
\hline $\begin{array}{c}\text { Stabilitas dan } \\
\text { tingqi busa }\end{array}$ & $\%$ & 66,24 & 60 & 63,80 & 61,80 & 59,24 & 67,34 & 63,72 & 61,23 & 65,04 \\
\hline
\end{tabular}

Keterangan :

$\mathrm{O}=$ Bentuk Oval; $\mathrm{CM}=$ Coklat Muda; $\mathrm{CT}=$ Coklat $\mathrm{Tua} ; \mathrm{CP}=$ Coklat Pucat 


\section{SIMPULAN}

Dari kesimpulan yang didapat bahwa sediaan sabun mandi padat dari ekstrak etanol ubi jalar ungu dapat di formulasikan sebagai sediaan sabun mandi padat dengan konsentrasi $10 \%$ yang sudah memenuhi syarat uji sediaan fisik sabun mandi padat.

\section{REFERENSI}

Andarwulan, N. \&Faradilla, R. F. 2012.Pewarna alami untuk pangan. Bogor: Seafast Center.

Anonim, 1979, Farmakope Indonesia, Edisi III, Hal 456, 458, 412, 459, 96.

Anonim, 2000, Parameter Standar Umum Ekstrak Tanaman Obat, Cetakan pertama, 10- 11,16, Depatermen Kesehatan Republik Indonesia, Jakarta.

Anonim, 1986 , Sediaan Galenik, 1, 11-25, Depatermen Kesehatan Refublik Indonesia, Jakarta. Badan Standarisas iNasional.Standar Nasional Indonesia (SNI). Sabun Mandi Padat. 1994.

Dewan Standarisasi Nasional 1994, Standar Mutu Sabun Mandi SNI 06-3532-1994, Jakarta.

Ginting, E.,J.S. Utomo, R. Yulifianti, dan M. Jusuf. 2011. Potensi ubi jalar Ungu Sebagai Pangan Fungsional. Iptek Tanaman Pangan 6(1) : 116- 138.

Hambali.,M., Mayasari, F.\&Noermansyah,F. 2014. Ekstraksi Antosianin dari ubi jalar dengan variasi konsentrasi solven dan lama waktu ekstraksi. Teknik Kimia, 20(2), 25-35.

Hopper.1951. Fat and Oilsdalam Keteran, S. 1986. Pengantar Teknolog iMinyak dan Lemak Pangan. Jakarta :Universitas Indonesia (UI-Press).

Idrus, Ahmad., Kun Harismah, Agus Sriyanto. 2013. Pemanfaatan Kemangi (Ocimum sanctum) Sebagai Subsitusi Aroma pada Pembuatan Sabun Herbal Antioksidan.Simposium Nasional TeknologiTerapan (SNTT): K-13-K-17:ISSN: 2339- 028X.

Juanda D dan Cahyono, 2000.Ubi Jalar, Budidaya Dan Analisis Usaha Tani, PenerbitKanisius.Yogjakarta..

Jusuf, M., Rahayuningsih, St. A. dan Ginting E. 2008.Ubi jalarungu. Warta Penelitian dan Pengembangan Pertanian.

Kamikaze, Dianthama. 2010. Studi Awal Permbuatan Sabun Menggunakan Campuran Lemak Abdomen Sapi dan Card Susu Aktif. Skripsi.Bogor :IPB. 